\title{
THE ROLE OF LEGAL AID ORGANIZATIONS (OBH) UNDERSTAND RIAU IN RESOLVING CHILDREN'S CASES IN PEKANBARU CITY
}

\section{Alpi Syahrin, Samariadi*, Al Fikri Lubis, Al Mario, Try Muhammad}

Universitas Islam Negeri Sultan Syarif kasim Riau, Riau University, Gajah Mada

University, Riau Islamic University, Riau Legal and Human Rights Advocacy

Center

msyahrin@uin-suska.ac.id*

ABSTRACT

Crimes are not only committed by adults against children, but there are also crimes committed by children. Crimes involving children often end up in court, and there are some differences that courts make when a child sits as a convict. Children facing the law, whether children conflict with the law (Bad Boy), Victim's Child, or Witness's Child, must be provided legal assistance and accompanied by legal aid or legal counsel. The type of research used is sociological juridical. Thus, there is a need for special assistance to $A B H$, to ensure the psychology of the child is not compromised. Legal aid organizations that are required to assist $A B H$ both outside and in the trial, also play a role in ABH's psychological assistance. OBH PAHAM Riau is present in the effort to fight for the guarantee and protection of the rights of marginalized/poor people as well as the enforcement of fair laws specifically in pekanbaru city, Riau.

Keywords: Role, OBH PAHAM Riau, Children's Case.

\section{Journal History}

Received : September17, 2020;

Reviewed : October 15, 2020;

Accepted : October 28, 2020;

Published : November 1, 2020

Copyright @2020 NLR. All right reserved. 


\section{INTRODUCTION}

Children are social beings as well as adults. The child needs others to be able to help develop his or her abilities, because the child is born with all the weaknesses so that without others it is impossible to reach a normal level of humanity. Children are social beings, the social development of the child requires the maintenance of compassion and a place for its development. Children also have different feelings, thoughts, wills that are all psychic totality and different traits and structures in each phase of development in childhood.

Children are an integral part of the continuity of human life and the sustainability of a nation and a State. Children who are part of the younger generation usually have a great concern for the problems of society, because at that age began to grow idealism (tend to expect perfection). ${ }^{1}$

Kariangan in Hadita (2020) Associated with the use of moral responsibility in the office, Roscoe Pound pointed out that in a society which people may assume that people who are on around him are people who civilized, as a result, in the event of an act that deviates would hold accountablethe parties that did such acts, as a result, in the view of Roscoe Pound there are four things that become the basis forapplying the moral

1 Wagiati Soetodjo, Hukum Pidana Anak, (Bandung: PT. Refika Aditama, 2006), p. 63-65.

2 Cynthia Hadita, Regional Autonomy Political Politics Of Regional responsibility,

namely: ${ }^{2}$

1. That other people will have the hope of a good and reasonable that created $t$ he appointment or conduct of the person's official;

2. That officials will keep its promise is based on the hope that is attached to it by a sense of morality on the citizens;

3. That they will act diligently and can be trusted in the interaction of position and work;

4. That they will refurbish anything that has ac ceptance of error or circumstances which do not unexpectedly been acceptance of erroneous or circumstances that are not presumed - would have thought, so they accept anything that should not be worthy and not will be received in ordinary circumstances.

The state guarantees the welfare of each of its citizens including the protection of the rights of the child which is a human right. Every child is entitled to survival, growth, and development and is entitled to protection from violence and discrimination as set out in Article 28B Paragraph (2) of the Constitution of the Republic of

Liability Reports To Regional Representatives In The Implementation Of Local Government, Nomoi Law Review, Volume 1, Issue 1, May 2020, p. 94. 
Indonesia year 1945. The child's rights are also attached to the child facing the law which includes the child as the perpetrator, victim, and witness. $^{3}$

Crimes are not only committed by adults against children, but there are also crimes committed by children. Crimes involving children often end up in court, and there are some differences that courts make when a child sits as a convict. In the study of aspects of criminal law, the question of determining a child's criteria even though it is expressly based on the age limit, but when examined some provisions in the Penal Code governing the issue of the age limit of the child, there is also diversity. The legal process that occurs in a child can inflict profound trauma on his life so that it needs optimal treatment, by taking preventive measures, settlement of litigation administration, rehabilitation, and social reintegration. ${ }^{45}$

The child is not to be in law, but to be built and guided in order to be a complete, intelligent and responsible human being as the next generation of the nation in the future. Children sometimes find difficult situations or circumstances that encourage children to commit acts that violate the values of law, religion, decency and decency. Many factors affect him such as, the circumstances

\section{${ }^{3}$ Explanation Regulations}

Government Number 8 Years 2017 About Ordinances Implementation Coordination, Monitoring, Evaluation Dan Reporting System Judicial Criminal Children.

4 Nandang sambas, Peradilan Pidana Anak di Indonesia dan Instrumen Internasional Perlindungan Anak Serta of the child himself, his family, the victim or the community. The treatment of children facing the law should not lead to stigmatization or labeling, as it will have a major impact on the future survival of the child.

Deviations of behavior or unlawful acts committed by children, cannot be released from fundamental social changes in people's lives, as a result of rapid development, the flow of globalization in the field of communication and information, advances in science and technology as well as changes in adult style and way of life. The presence of children who behave in a deviant way, especially those who commit crimes, is interesting to be reviewed further.

The child facing the law $(\mathrm{ABH})$ is basically not a perpetrator, but rather a victim. The victim of the child's situation or environment grows. For example, a child consuming narcotics or illegal drugs is a victim, a victim of his home environment or his play environment who forces him or teaches him to take the drugs. Another example is a child who sexually abuses a peer. So the child could have been the victim of pornography that was rife in various media, the child exemplifies what he saw without understanding the right or wrong actions taken against his friend. Therefore, children who face the law should be protected and get

Penerapannya, (Yogyakarta: Graha Ilmu, 2013), p. 7.

${ }^{5}$ Explanation Regulations

Government Number 8 Years 2017

About Ordinances Implementation Coordination, Monitoring, Evaluation Dan Reporting System Judicial Criminal Children. 
legal justice so that criminal or criminal justice is the last step or last resort for the bad boy, given the future and the growth of the child.

In its development Indonesia has had a special rule on child protection namely Law No. 4 of 1979 on Child Welfare, Law No. 3 of 1997 on Children's Courts which was subsequently replaced with Law No. 11 of 2012 on the Child Criminal Justice System and Law No. 35 of 2014 on changes to Law No. 23 of 2002 on Child Protection. Even though we already have a good set of rules but still feel less effective in resolving cases of children facing the law.

Every citizen has the same position before the law without exception which includes the right to be defended (acces to legal counsel), treatedequally before the law (equality before the law), justice for all(justicefor all). The provision of legal aid itself is stipulated in Law No. 16 of 2011 on Legal Aid. The implementation of legal aid aims to guarantee and fulfill the right for legal aid recipients to obtain access to justice. In addition, to realize the constitutional rights of all citizens in accordance with the principle of equality of standing in the law. ${ }^{6}$

Law No. 48/2009 on Judicial Power, Article 56 states:

1) Everyone who gets caught in a case deserves legal aid.

2) The state bears the cost of litigation for justice seekers who cannot afford it.

Based on the above exposure, child protection must be pursued by everyone, parents, families, society, government and state. Article 20 of Law No. 35/2014 on Child Protection specifies: "States, governments, communities, families, and parents are responsible for the maintenance of child protection". Aspects of child protection law need to be considered because child protection and child criminal justice are one way of protecting the child in its future growth. Legal protection in this case, contains the understanding of child protection in the face of the law $(\mathrm{ABH})$.

Children facing the law, whether children conflict with the law (Bad Boy), Victim's Child, or Witness's Child, must be provided legal assistance and accompanied by legal aid or legal counsel. Thus, there is a need for special assistance to $\mathrm{ABH}$, to ensure the psychology of the child is not compromised. Legal aid organizations that are required to assist $\mathrm{ABH}$ both outside and in the trial, also play a role in $\mathrm{ABH}$ 's psychological assistance. $\mathrm{OBH}$ PAHAM Riau is present in the effort to fight for the guarantee and protection of the rights of marginalized/poor people as well as the enforcement of justice especially in Pekanbaru city, Riau.

\section{METHOD}

The type of research used is sociological juridical, which in this study, is done by direct field to collect the primary data, and using

${ }^{6}$ Articles 3 letter a and b, Law

No. 16/2011 on Legal Aid. 
descriptive methods, because this study aims to describe (describe), record, analyze, in accomplish the phenomenon that occurs according to the reality of living in society. This research was conducted in the jurisdiction of ${ }^{7}$ Pekanbarucity, because the Legal Aid Organization( $\mathrm{OBH})$ ) PAHAM Riau is a legal aid organization that has the authority to carry out its duties in pekanbrucity, and has a complete archive and documents on cases related to research completed by the Legal Aid Organization (OBH)) PAHAM Riau

\section{DISCUSSION}

\section{Role of legal aid organization (OBH) Paham Riau dalam penyelesaian perkara anakin kota pekanbaru.}

Children Who Face the Law, whether Children Conflict with the Law (Bad Boy), Victim's Child, or Witness's Child, must be provided legal assistance and accompanied by legal aid or legal counsel. Thus, there is a need for special assistance to $\mathrm{ABH}$, to ensure the psychology of the child is not compromised. Legal aid agencies that are required to assist $\mathrm{ABH}$ both outside and in the trial, also play a role in psychologicalassistance.

Article 23 paragraph (1) of Law No. 11 of 2012 on the Child Criminal Justice System which reads: "At every level of examination, the Child shall be given legal assistance and accompanied by a Public

${ }^{7}$ Hilman Hadikusuma, Metode pembuatan kertas kerja atau skripsi ilmu hukum, (Bandung: CV.Mandar Maju, 1995), p. 61.

8 Eka N.A.M Sihombing, Cynthia Hadita, Analisis Wacana
Counselor or other companion in accordance with the provisions of the legislation". Thus, Children Who Face the Law, whether Children Conflict with the Law (Bad Boy), Victim's Child, or Witness's Child, must be provided legal assistance and accompanied by legal aid or legal counsel.

Andika Yudha Pratama in Eka NAM Sihombing and Cynthia Hadita said that the implementation of decentralization in Indonesia is actually not something new, this discussion of decentralization was discussed since the 1950s along with the renewal of reforms in the democratic system in developing countries. The big agenda of the implementation of decentralization, including in Indonesia, is an effort to strengthen the role of the government in organizing the country through the empowerment of local governments. Furthermore, in its development, the implementation of decentralization in Indonesia did not just stand alone, because another variant of the implementation of decentralization, namely asymmetric decentralization, was raised. ${ }^{8}$

The Legal Aid Organization itself in its devotion to the community has the following functions or roles:

\section{Public service}

This is related to socioeconomic conditions in which most Indonesians are classified as

Hukuman Pancung Di Provinsi Aceh, Jurnal Legislasi Indonesia, Vol. 6, No. 4, December (2019). 
incapable (onvermogen)or lessable (mindervermogen)to use and pay for the services of advocates so that $\mathrm{OBH}$ provides its services free of charge.

\section{Social Education}

This relates to socio-cultural conditions in which $\mathrm{OBH}$ with a mature and systematic planning and practical working method should provide explanations and instructions to educate the public to be more aware and understand its rights and obligations according to the law so as to foster and develop awareness of the law of society.

\section{Improvement of the rule of law}

This relates to socio-political conditions where the role of $\mathrm{OBH}$ is not only limited to improvements in the judiciary in general and the defence profession in particular, but can also do the work of the Ombudsman as the participation of the public in the form of control with its criticisms and suggestions to improve the limping or correct the actions of the rulers that harm the community.

4. Reform of the law.

There are many laws that need to be updated because they do not meet the legal needs of the people, even if they impede or contradict the circumstances. In this case, $\mathrm{OBH}$ can pioneer proposals forlaw reformtowards law reform inaccordance with the needs of the community.

\section{Practical training}

9 Abdurrahman, Aspek-Aspek Bantuan Hukum di Indonesia, (Jakarta: Cendana Press, 1983). p. 241.
$\mathrm{OBH}$ cooperates with the Faculties of Law. For the Faculties of Law, OBH can be used as a practice training ground for law students in order to prepare themselves to become legal scholars by testing the theories studied with reality so as to gain experience. For $\mathrm{OBH}$, the cooperation can help maintain $\mathrm{OBH}$ idealism in addition to obtaining contributions of thoughts and suggestions in the form of scientific ideas as well as sources and participation of students from the faculty for the development and progress of $\mathrm{OBH}{ }^{9}$

In order to perform its functions and roles, $\mathrm{OBH}$ made the following efforts:

a. To provide legal assistance and/or general defense covering all work or advocacy services to their clients in or out of court;

b. Hold lectures, discussions, lighting, publication of books and brochures, and so on;

c. Cooperate with government agencies/agencies/agencies and non-governmental agencies;

d. Providing themselves as a platform for legal practice exercises for Students of the Faculty of Law.

While OBH function on child handlers facing the law, namely:

1. Psychological assistance to the Child.

2. Encouraging the Community to participate in the handling of Children Facing the Law by creating Community Services for 
Children, especially for children of minor offenders.

3. Conduct promotions or campaigns on the protection of women and children.

4. Promote gender and child justice policies.

The role of $\mathrm{OBH}$ in the handling of Children facing the Law, namely

a) Against children who conflict with the law (Bad Boy), the form of mentoring:

1) Conduct assistance in every level of examination, namely the stage of investigation, investigation and examination stage in court;

2) Perform mentoring when Diversion is performed; Dan

3) Giving a plea at trial

b) To the Child as a victim (Victim's Child), the form of mentoring:

1) Conducting assistance when the Victim's Child reports to the Police, about the crimes he experienced himself;

2) Psychological mentoring;

3) Monitoring at the time of examination in court; Dan

4) Do mentoring when Diversi is done.

c) To the Child as a Witness, the form of mentoring:

1) Conduct assistance when the Witness's Child reports to the Police, about the crimes seen, heard and/or experienced by himself;

2) Psychological mentoring;

3) Monitoring while testifying in court; Dan
4) Do mentoring when Diversi is done.

Children Facing The Law (ABH)

The Child Facing the Law $(\mathrm{ABH})$ is basically not a perpetrator, but rather a victim. The victim of the child's situation or environment grows. For example, a child consuming narcotics or illegal drugs is a victim, a victim of his home environment or his play environment who forces him or teaches him to take the drugs.

An example of a case that OBH PAHAM Riau has provided legal aid and sampled in this study is, a child who committed sexual abuse against his peers. So the child could have been the victim of pornography that was rife in various media, the child exemplifies what he saw without understanding the right or wrong actions taken against his friend. Therefore, Children Facing the Law should be protected and get legal justice so that criminal or criminal justice is the last step or last resort for the Bad Boy, given the future and the growth of the child.

In this case OBH PAHAM Riau has played an active role in providing legal assistance to the child such as doing assistance in every level of examination, i.e. the stage of investigation, investigation and examination stage in the court, conducting assistance when diversi is done and giving the defense in the trial from the beginning of the handling of the case until it is completed, the child is charged with sections 81 and 82 of the Child Protection Act until it enters the proceedings, OBH PAHAM Riau tries to the maximum possible attempt to diversion, but the panel of judges argues that until the proceedings are 
carried out by a prison sentence. This has an impact on the Education of Children Facing the Law.

Many of the losses will be suffered by children facing the law, one of which is in terms of education. Children who face the law will certainly lose a lot of time that should be able to be used to study or attend school because the child will spend a lot of time in the Special Child Coaching Institute (LPKA). What's more, education facilities in LPKA in Indonesia are still far from a goodcategory.

Thus it can be concluded that the child who undergoes his or her uptime in the correctional institution will lose the opportunity to study formally. The detention of children in correctional institutions in Indonesia has created a domino effect for the child's life. Things that become a child's right will be diminished even lost. The future of children held in prison will also be threatened as will the impacts on the child's psychological and education. The pressure that children may feel throughout the judicial process until detention coupled with unsankable educational facilities further reduces the child's chances of having a bright period.

\section{Child As Victim (Victim's Child)}

For example, the case of child as a victim who has OBH PAHAM Riau is a child victim of sexual abuse committed by adults. OBH PAHAM Riau has provided legal assistance such as:

1. assistance when the Victim's Child reports to the Police, about the crimes he experienced himself,

2. To provide psychological assistance by working with PPPA (Center for Women and Child
Empowerment) and Psychologists to recover the psychological toll child.

3. Monitoring during the examination in court.

The Inhibitory Factor of The Implementation of Legal Aid By Legal Aid Organization (Obh) Understand Riau In The Settlement of Child Cases in Pekanbaru City, External Factors:

Thef-actors that hinder the implementation of legal aid according to Soerjono Soekanto are as follows:

1. The legal factor itself,the law to be discussed is limited to the law only. Disruption to law enforcement stemming from the law is likely caused by:

a) The absence of the principles of the law resulted in the absence of legal certainty;

b) There are no executive regulations that are needed to place legislation.

c) The obscurity of the meaning of words in the law resulted in a discrepancy in their interpretation and application.

1. Law EnforcementFactor, sociologically every law enforcement has a position and role. The problem arising from law enforcement factors is the application of the role of law enforcement. Obstacles that require countermeasures include:: 
a. Limited ability to place themselves in the role of the other party with whom he interacts;

b. Low aspiration rate;

c. The excitement is so limited to thinking about the future, that it is very difficult to make a projection;

d. The absence of the ability to delay the restoration of a particular need, especially material needs;

e. The lack of innovative power is actually a pair of conversatism.

2. Factor of facilities or facilities

Facilities and facilities play an important role in law enforcement. Without such advice and facilities, law enforcement cannot run in a lancer and is fit for purpose. These facilities and facilities include educated and skilled human resources, good organization, adequate equipment, sufficient finanskills, and so on

\section{Masyarakafactor $\mathbf{t}$}

The related soy factor is the environment in which the law applies or is applied. Public opinion on the law also affects law enforcement with law enforcement.one of the opinions of the public is about the meaning of the law that is considered identical to the officer. Such an opinion will cause the public to comply with the law if there are officers on guard

\section{Cultural Factors}

Culture is the result of copyright and taste based on human nature in the association of life. The law must be made in accordance with the conditions of society and must not be contrary to the culture that lives in society. Cultural diversity in Indonesia affects law enforcement efforts in Indonesia. The provision stipulated in one law may apply to a region, but it cannot necessarily be implemented in anotherarea.

2. Internal Factor (Psychological Impact)

a. Children Facing the Law (ABH)

$\mathrm{ABH}$ will certainly feel an unpleasant impact on his life. Children who commit crimes and are forced to be punished in prison will grow and develop in an environment that is not ideal and will indirectly shape the child's personality. As $\mathrm{OBH}$ PAHAM Riau research team interviewed a sample in this study, namely a child who sexually abused his girlfriend and should be placed in a child detention center, very influential to the child psychologically, they became reluctant to talk to strangers, and more closed themselves.

Based on the information from paham riau advocacy team took a long time 
to approach, the child was reluctant to talk, and spoke only just, the child just wanted to talk to first in persuaded by his parents. So it becomes an obstacle for the advocacy team to be able to know the chronological case in detail as a mentoring material in the trial.

\section{b. Child As Victim (Victim's Child)}

Not only children who face the law $(\mathrm{ABH})$, Anak Korban will also experience psychological impact, in this study obh paham riau research team took samples of children who were victims of sexual abuse committed by adults. As a child who is a victim of sexual abuse, he will be traumatized by the circumstances he has experienced, so that the child is reluctant to talk, it is difficult to get along again with his peers due to shame or fear. Especially the child as a victim who sampled in this study had a slight lack of thinking, he was not like a friend the same age as him, so even though he was 15 years old but he still sat in elementary school.

Psychological impact as a victim of sexual harassment and also lacking in thinking, PAHAM Riau Advocacy team experienced a slight obstacle when conducting assistance at Pekanbaru Police. So the ADVOCACY TEAM OBH PAHAM Riau works with the Center for the Protection of
Women and Children (PPPA), as well as the Pekanbaru State Prosecutor's Office to seek more assistance done by a Psychologist, to restore the child's mentalstate.

\section{CONCLUSION}

Efforts made by $\mathrm{OBH}$ PAHAM Riau in providing legal assistance to children facing the law $(\mathrm{ABH})$ such as conducting assistance in every level of examination, namely the investigation stage, investigation and examination stage in the court, conducting assistance when diversi is done and providing defense in the trial from the beginning of the handling of the case until completion. Child As Victim (Victim's Child) OBH PAHAM Riau has provided legal assistance such as:

1. assistance when the Victim's Child reports to the Police, about the crimes he experienced himself,

2. To provide psychological assistance by working with PPPA (Center for Women and Child Empowerment) and Psychologists to recover the psychological toll child.

3. Monitoring during the examination in court.

As well as being a factor in inhibiting the implementation of legal aid by OBH PAHAM Riau both as a child facing the law $(\mathrm{ABH})$ and the victim's child is a psychological factor, they become traumatized, closed with strangers, difficult to talk to and become more difficult to get alongagain. 


\section{REFERENCES}

Hadikusuma, Hilman., Metode pembuatan kertas kerja atau skripsi ilmu hukum, Bandung: CV.Mandar Maju, 1995.

Sambas, Nandang., Peradilan Pidana Anak di Indonesia dan Instrumen Internasional Perlindungan Anak Serta Penerapannya, Yogyakarta: Graha Ilmu, 2013.

Sihombing, Eka N.A.M., Cynthia Hadita, Analisis Wacana Hukuman Pancung Di Provinsi Aceh, Jurnal Legislasi Indonesia, Vol. 6, No. 4, December (2019).Hadita, Cynthia., Regional Autonomy Political Politics Of Regional Liability Reports To Regional Representatives In The Implementation Of Local Government, Nomoi Law Review, Volume 1, Issue 1, May 2020, p. 94. Abdurrahman, Aspek-Aspek Bantuan Hukum di Indonesia, Jakarta: Cendana Press, 1983. Soetodjo, Wagiati., Hukum Pidana Anak, Bandung: PT. Refika Aditama, 2006.

Constitution of the Republic of Indonesia year 1945.

Penal Code.

Law No. 48/2009 on Judicial Power.

Law No. 16/2011 on Legal Aid.

Law No. 35/2014 on Changes to Law No. 23/2002 on Child Protection.

Law No. 35/2014 on Changes to Law No. 23/2002 on Child Protection. 